\title{
Temporal and spatial differences of the under-ice microbiome are linked to light transparency and chlorophyll-a
}

\author{
Ulrike Obertegger 10
}

Received: 2 November 2021 / Revised: 11 January 2022 / Accepted: 15 January 2022 / Published online: 29 January 2022

(C) The Author(s) 2022

\begin{abstract}
Under-ice community dynamics are barely understood. Temporal and spatial studies are needed to fully understand the consequences of a declining ice cover on microbial biodiversity. Here, bacterial communities of different years (2015, 2017-2021) and layers (upper and lower euphotic layer, euphotic layer, hypolimnion) were assessed by Illumina sequencing of the $16 \mathrm{~S}$ rRNA gene. Alphaand beta-diversity of summer and under-ice hypolimnetic communities were similar, and a seasonal difference was found only when excluding summer hypolimnetic communities. Similarly, in non-metric multidimensional scaling (NMDS), summer and under-ice communities were different even though hypolimnetic communities were similar. Investigating under-ice conditions, the year 2017 showed highest under-ice light and chlorophyll-a while 2021 showed no under-ice light and lowest chlorophyll-a. Under-ice communities were not linked to layer differences implying that a spatial distinction under ice was less important than in summer, especially in years with
\end{abstract}

Handling Editor: Diego Fontaneto

Supplementary Information The online version contains supplementary material available at https://doi.org/10.1007/ s10750-022-04802-2.

U. Obertegger $(\bowtie)$

Fondazione Edmund Mach, Via E. Mach 1,

38010 San Michele all' Adige, Italy

e-mail: ulrike.obertegger@fmach.it little or no under-ice light. Most under-ice bacterial classes and ASVs showed direct and indirect dependencies on light availability and primary production. Similarly in NMDS with only under-ice communities, light transparency and primary production were important. In the future, ice conditions with less snow cover might lead to bacterial communities similar to that of high-light years $(2017,2018,2020)$.

Keywords Lake Tovel $\cdot$ 16S rRNA gene $\cdot$ Under-ice communities · ANCOM · Hypolimnion · Euphotic layer

\section{Introduction}

Half of the world's lakes periodically freeze and form an ice cover (Verpoorter et al., 2014). The ice cover shields the aquatic environment from its surroundings, and any input of radiation, gases, nutrients, and organisms is halted or hindered. Accordingly, winter bacterial communities show marked differences between conditions with and without an ice cover (Butler et al., 2019). The under-ice period is biologically active and important for biogeochemical cycles throughout the year, despite low temperatures and reduced nutrient remineralization due to low protozoan grazing (Bertilsson et al., 2013). Low ambient temperature is not an obstacle for bacterial life (Price 
$\&$ Sowers, 2004), and mostly nutrients such as carbon and no temperature limit bacterial growth under ice (Bižić-Ionescu et al., 2014). Snow-free ice can show a high transmittance for radiation (Bolsenga \& Vanderploeg, 1992; Jewson et al., 2009), and thus light-driven mixing (Kirillin et al., 2012; Yang et al., 2017) and photosynthesis (Garcia et al., 2019) occur under ice. Especially, light differences determine the composition of under-ice phytoplankton (Charvet et al., 2014; Kalinowska \& Grabowska, 2016; Hrycik \& Stockwell, 2021), and the stimulation of under-ice primary production by increased light availability also enhances the activity of aerobic heterotrophic bacteria (Garcia et al., 2019).

The under-ice microbial community is taxonomically distinct from the summer one and can be associated with multiple reductive metabolic processes, fermentations, and pathways for the mobilization and degradation of complex organic matter (Bertilsson et al., 2013; Vigneron et al., 2019; Cruaud et al., 2020). Generally, bacteria of the phylum Verrucomicrobia are abundant under ice (Tran et al., 2018; Mikhailov et al., 2021) and show a high diversity of metabolic functions (Tran et al., 2018). Under-ice bacterial communities can rapidly respond to altered environmental conditions by moving to lower depths (Garcia et al., 2019) or through selection or phenotypic plasticity (Monier et al., 2014). Within the ice cover and snow, a specific bacterial community is found showing compositional shifts from winter to spring (Llorens-Marès et al., 2015). The extent of the annual ice cover determines shifts in the aquatic bacterial community composition and structure (Beall et al., 2016) and influencesf the rate of nitrate accumulation and linked bacterial nitrification with important implications for the spring nutrient ratio (Powers et al., 2017).

While the number of studies investigating under-ice conditions is growing, their number is still far below those focussing on summer, and research on under-ice microbial communities should be intensified (Bertilsson et al., 2013; Butler et al., 2019). There is increasing evidence that winter sets the basis for the following seasons (Hampton et al., 2017; Powers et al., 2017), and winter dynamics of the lake's microorganisms are important for understanding bacterial community succession in the following ice-free period (Tulonen et al., 1994; Twiss et al., 2012; Bertilsson et al., 2013). While a spatial distribution of nutrients is found under ice (nitrogen: Powers et al., 2017; organic compounds: Rue et al., 2020), most microbial studies (e.g. Bashenkhaeva et al., 2015; Beall et al., 2016; Butler et al., 2019; Vigneron et al., 2019) focus on surface samples (but see Pernthaler et al., 1998; Bižić-Ionescu et al., 2014; Matyugina \& Belkova, 2015).

Climate change leads to reduced ice cover on lakes and rivers (Magnuson et al., 2000; Benson et al., 2012) with effects on lake physics (O'Reilly et al., 2015), chemistry (Flaim et al., 2020), and biology (Beall et al., 2016). In Lake Tovel, ice-in is delayed by 5.1 days per decade (Flaim et al., 2020), and changes in under-ice dissolved oxygen depend on snow cover and depth (Obertegger et al., 2017). To fully understand the consequences of declining ice cover on microbial biodiversity, a temporal and spatial study is needed. Here, summer and under-ice bacterial communities as determined by the 16S rRNA gene of different layers of the euphotic zone and the hypolimnion were compared during six years (2015, 2017 to 2021). The objectives were (i) to assess differences in alpha- and beta-diversity between summer and under-ice communities; a higher alphaand beta-diversity during summer than under ice was expected because of less nutrients and less environmental heterogeneity under ice than during the openwater summer season. A similarity between hypolimnetic summer and under-ice bacterial communities was, furthermore, hypothesized because the hypolimnion is dark and cold during both seasons. (ii) To assess the importance of environmental conditions for under-ice bacterial communities; bacterial diversity is influenced by under-ice light (Garcia et al., 2019), and thus a higher alpha- and beta-diversity in years with reduced snow cover and high-light transparency than in years with snow cover and reduced light transparency was hypothesized. (iii) To assess which bacterial taxa increased or decreased their abundance (a) from summer to under ice and (b) between years considering environmental differences under ice. The distinction of years regarding ice and snow cover is according to the lake ice continuum concept (Cavaliere et al., 2021). This study is the first giving a comprehensive overview over taxonomic changes in under-ice microbial communities over multiple years, an important precondition to understanding the consequences of ice loss for microbial communities. 


\section{Methods}

Site description and sampling

Lake Tovel (LTER site IT09-005-A; 46.261 ${ }^{\circ} \mathrm{N}$, $10.949^{\circ} \mathrm{E} ; 1178 \mathrm{~m}$ above sea level (asl)) is a glacial lake (area: $0.4 \mathrm{~km}^{2}$; maximum depth: $39 \mathrm{~m}$; mean depth: $19 \mathrm{~m}$; volume: $7.4 \times 10^{6} \mathrm{~m}^{3}$ ) located in the Brenta Dolomites (Trentino, Italy). The lake is generally frozen from December to mid-April (2009-2021: mean duration of ice cover $=126$ days). Several layers over the deepest part of the lake were sampled for bacterial communities: the euphotic (0-20 $\mathrm{m} ; 1 \%$ of light reaches approximately a depth of $23 \mathrm{~m}$, Cellamare et al., 2016), upper (0-3 m) and lower euphotic layer (3-25 m), and the deep hypolimnion (30-35 m). In 2015, 2017, and 2018, the euphotic layer was sampled; in 2018, the upper euphotic layer was additionally sampled, and from 2019 onwards, the euphotic layer was divided into an upper and lower euphotic layer; the deep hypolimnion was continuously sampled (Table 1). The splitting of the euphotic layer was related to high transparency to ultraviolet radiation in the first $3 \mathrm{~m}$ of the water column (Obertegger et al., 2008). The euphotic, upper, and lower layers were sampled with a tube and the deep hypolimnion was sampled merging Ruttner bottle samples from 30 and $35 \mathrm{~m}$ depths. Samples from July, August, and September were considered summer samples. Under-ice sampling was done once during winter (2015-01-28, 2017-01-11, 2018-0130, 2019-01-22, 2020-02-04, 2021-02-08), ranging from 26 to 65 days after ice-in (Table 2) when ice thickness and road accessibility allowed safe access for sampling, a common problem for sampling on ice (Block et al., 2019; Hazuková et al., 2021).

Table 1 Sampling scheme over the deepest part of the lake; $x$ indicates sampling

\begin{tabular}{|c|c|c|c|c|c|c|}
\hline \multirow[t]{2}{*}{ Layer (m) } & \multicolumn{6}{|l|}{ years } \\
\hline & 2015 & 2017 & 2018 & 2019 & 2020 & 2021 \\
\hline $0-20$ & $\mathrm{x}$ & $\mathrm{x}$ & $\mathrm{x}$ & & & \\
\hline $3-20$ & & & $\mathrm{x}$ & $\mathrm{x}$ & $\mathrm{x}$ & $\mathrm{x}$ \\
\hline $3-25$ & & & & $\mathrm{x}$ & $\mathrm{x}$ & $\mathrm{x}$ \\
\hline $30-35$ & $\mathrm{x}$ & $\mathrm{x}$ & $\mathrm{x}$ & $\mathrm{x}$ & $\mathrm{x}$ & $\mathrm{x}$ \\
\hline
\end{tabular}

Environmental variables under ice

For each sampling, water temperature, percent dissolved oxygen saturation (\%DO), conductivity, and $\mathrm{pH}$ were measured with a multiparametric probe (Idronaut Ocean Seven 316 Plus) at 1-m intervals. Water samples were taken with a bottle at 5-m intervals for nutrients and absorbance measurements at $254 \mathrm{~nm}$. Nutrient analyses were according to APHA (2017). Secchi disk depth was recorded as a proxy for light transparency. Profiles of chlorophyll- $a$ (chl- $a$ ) were taken with a FluoroProbe (bbe moldaenke); profiles of 2015 and 2020 were missing because of a malfunctioning computer connected to the probe. Water samples for chl- $a$ were taken from the upper 0-20 layer with a tube, and chl- $a$ was extracted from 1 L with $90 \%$ acetone and determined spectroscopically according to the trichromatic method (Rice et al., 2017). For absorbance measurements, water samples $(100 \mathrm{ml})$ were filtered (Whatman glass microfiber filters $\mathrm{GF} / \mathrm{F}$ ), and the absorbance at $254 \mathrm{~nm}$ was used as proxy for dissolved organic carbon (DOC; Summers et al., 1987).

The coefficient of light attenuation for photosynthetically active radiation $\left(\mathrm{kd}_{\mathrm{PAR}}\right)$ was assessed as average for the central daylight hours (10:30 to 14:00) with high-frequency sensors (HOBO by Onset UA002-08 Pendant Temperature/Light Data Logger), deployed at discrete depths $(1,2,5,10,15,20 \mathrm{~m})$. The average $k d_{\text {PAR }}$ for five days before sampling was reported to account for any legacy effect of light on bacterial growth, and no longer period was used to consider the fast temporal variation of bacterial communities (Grubisic et al., 2017). Precipitation from ice-in to sampling was recorded by the onshore meteorological station; when data were missing, the close-by Cles weather station $\left(46.361^{\circ} \mathrm{N}, 11.040^{\circ} \mathrm{E}\right.$; $656 \mathrm{~m}$ asl; $13 \mathrm{~km}$ from Lake Tovel) was used.

DNA extraction, sequencing, and analysis of $16 \mathrm{~S}$ rRNA gene sequences

For DNA extraction of free-living bacteria, generally $1.5 \mathrm{~L}$ of water from each layer was gently vacuumfiltered onto sterile $0.2 \mu \mathrm{m}$ membrane filters (Supor 200 Membrane Disc Filters, 47 mm; Pall Corporation, East Hills, NY, USA). Filters were stored at $-80{ }^{\circ} \mathrm{C}$. DNA was extracted from the filters with the PowerWater DNA isolation kit (MOBIO Laboratories Inc, 
Table 2 ANCOM-BC testing for significant increase or decrease in abundance of ASVs from summer to under-ice hypolimnetic communities with random ( $n=100$ times) downsampling of summer communities to the number of under-ice ones; the lower and upper range report the range of $\log _{\mathrm{e}}$-fold change from summer to under ice; only ASVs with consistent doubling or halving in all permutations were considered; unclassified (unclass), Gammaproteobacteria (Gamma), Alphaproteobacteria (Alpha)

\begin{tabular}{|c|c|c|c|c|c|c|c|}
\hline \multirow[t]{2}{*}{ Phylum } & \multirow[t]{2}{*}{ Class } & \multirow[t]{2}{*}{ Order } & \multirow[t]{2}{*}{ Lineage } & \multirow[t]{2}{*}{ Clade } & \multirow[t]{2}{*}{ Tribe } & \multicolumn{2}{|l|}{ Range } \\
\hline & & & & & & Lower & Upper \\
\hline Bacteroidota & Bacteroidia & Flavobacteriales & Flavobacteriaceae & Flavobacterium & Unclass & -5.0 & -1.8 \\
\hline \multirow[t]{7}{*}{ Proteobacteria } & Gamma & Burkholderiales & betI & betI-B & Rhodo & -4.2 & -0.8 \\
\hline & & & Rhodocyclaceae & Sulfuritalea & Unclass & 0.8 & 2.9 \\
\hline & & & betII & Pnec & PnecA & 1.0 & 2.1 \\
\hline & & & betII & Pnec & PnecC & 1.8 & 3.0 \\
\hline & & & betI & betI-A & Unclass & 1.4 & 3.1 \\
\hline & & & betII & Pnec & PnecC & 2.2 & 3.9 \\
\hline & Alpha & Rickettsiales & Rickettsiaceae & Unclass & Unclass & 1.6 & 2.8 \\
\hline \multirow[t]{2}{*}{ Actinobacteriota } & Actinobacteria & Unclass & Unclass & Unclass & Unclass & 1.2 & 2.6 \\
\hline & Acidimicrobiia & Microtrichales & acIV & acIV-D & Lamia & 1.7 & 2.9 \\
\hline
\end{tabular}

CA, USA). Environmental DNA was PCR-amplified by targeting a $\sim 460$-bp fragment of the 16S rRNA variable region $\mathrm{V} 3-\mathrm{V} 4$ using the bacterial primer set 341F (5' CCTACGGGNGGCWGCAG $3^{\prime}$ ) and 805R (5' GACTACNVGGGTWTCTAATCC $3^{\prime}$ ) (Herlemann et al., 2011) with degenerate bases as suggested by Apprill et al. (2015) and overhanging Illumina adapters. PCR amplification, library construction, and analyses are described in detail in Obertegger et al. (2018).

Sequences were analysed using libraries DADA2 (Callahan et al., 2016) and Bioconductor (Huber et al., 2015) in R 4.0.2 (R Core Team, 2020). With DADA2, Illumina-sequenced amplicon errors are modelled and corrected, and amplicon sequence variants (ASVs) are provided (Callahan et al., 2017). In DADA2, the following settings, critical for ASV identification, were used: truncation length: 250, 250; trimLeft: 17 , 21; maxEE: 2, 5. Only bacterial reads were used for taxonomic assignment that was carried out using the TaxAss workflow (Rohwer et al., 2018) incorporating the Freshwater Microbial Field Guide (https://github. com/McMahonLab/FWMFG, accessed on September 2021) and SILVA 138 release dataset (Quast et al., 2012). The class SL56_marine group has been incorrectly referred to as a marine group (Mehrshad et al., 2018), and thus the extension marine group was left out in the name of this bacterial class. The ASVs table was rarefied without replacement to 15,563 sequences per sample, obtaining 2653 bacterial ASVs in 16 under-ice and 39 summer samples.

Statistical analyses

All statistical analyses were done using R 4.0.2 ( $\mathrm{R}$ Core Team, 2020). For summer versus under-ice comparisons of alpha- and beta-diversity, the unbalanced dataset (i.e. not all layers were sampled during all years) impeded a comparison between layers, and therefore the focus was on seasonal means. The nonparametric Mann-Whitney U test, that is appropriate for small sample size and does not rely on balanced samples (Sokal \& Rohlf, 1995), was used to compare mean richness between seasons. Furthermore, the \% under-ice ASVs unique to layers across years and unique for years across layers, respectively, were determined by Venn diagrams (Supplementary Fig. 1) using libraries venn (Dusa, 2021) and MicEco (Russel, 2021). As a measure of beta-diversity (Anderson et al., 2006), the variation of distances between bacterial communities and their centroid dependent on season (summer versus under ice; R function "betadisper" with bias.adjust $=$ TRUE to consider the unequal sample size) was tested.

For under-ice samples, a principal component analysis (PCA) was performed with standardized environmental variables to investigate environmental variability of layers. Values of water temperature, 
$\% \mathrm{DO}$, and nutrients were averaged within the respective layer. For missing \%DO in 2018 (from $20 \mathrm{~m}$ downwards) and in 2019 (whole profile), a mean yearly value based on existing data from the respective layer was used. For missing temperature in 2018 (from $20 \mathrm{~m}$ downwards), the fluoroprobe temperature data were used, while in 2019 the same procedure as for $\%$ DO was applied. Furthermore, standardized environmental variables were used as input in betadisper to estimate the environmental diversity between layers. In betadisper analysis, all samples from the euphotic layers were merged to compare them to the hypolimnion to avoid a comparison between samples of low sampling effort (Table 1). Differences in $\mathrm{kd}_{\mathrm{PAR}}$ between years were assessed by ANOVA and post hoc Turkey honest significant difference (HSD) test, taking into account multiple testing.

Two non-metric multidimensional scaling (NMDS) analyses were performed with ASVs using abundanceweighted Bray-Curtis dissimilarity as distance. In the first one, summer and under-ice communities were used to investigate seasonal similarities. To further investigate any clustering of communities, an analysis of similarity (ANOSIM) was applied using abundance-weighted Bray-Curtis dissimilarity and 9999 simulations. ANOSIM ranks dissimilarities instead of actual distances to test for differences between communities based on a factor, here season (summer versus under ice); the closer the $\mathrm{R}$ index is to 1 , the more the communities within a group are similar to each other and dissimilar to communities in other groups. In the second NMDS, only under-ice communities were used and environmental predictors were related to the ordination by environmental fitting; the first two principal components of the PCA with environmental predictors and single environmental predictors (\% DO, temperature, $\mathrm{pH}$, conductivity, nutrients) were used as environmental predictors, respectively. Only for the under-ice-specific NMDS, the $95 \%$ confidence intervals for the centroid of communities belonging to years or layers were drawn into the ordination using package ggordiplots (Quensen, 2020). A permutational multivariate ANOVA (PERMANOVA) and ANOSIM were used complementary to the under-ice-specific NMDS. In PERMANOVA, Bray-Curtis dissimilarity was used to partition the variability of communities between years and layers, respectively.
For identifying differences in ASV abundance between bacterial communities (summer versus under-ice communities; summer versus under-ice hypolimnetic communities; low-light versus highlight under-ice communities), the analysis of composition of microbiomes (ANCOM) was used that has a good control of the false discovery rate and is superior with respect to other methods (Weiss et al., 2017). Here, ANCOM with bias correction (ANCOM-BC) was applied using library ANCOM-BC (Lin \& Peddada, 2020). In comparisons between summer and under-ice communities, summer samples were randomly down-sampled (100 times) to the number of under-ice samples to decrease the influence of specific summer months, and only the ASVs that i) were statistically significant across all combinations and ii) showed at least a doubling or halving across all combinations were considered and their $\log _{\mathrm{e}}$-fold change was reported.

PERMANOVA, ANOSIM, NMDS, and environmental fitting were performed using package vegan (Oksanen et al., 2020), and plots were made using ggplot2 (Wickham, 2016).

\section{Results}

Summer versus under-ice bacterial communities

Mean summer ASV richness (mean \pm standard deviation richness ASV $=269 \pm 58$ ) was not statistically significantly different from under-ice richness (richness $_{\mathrm{ASV}}=289 \pm 55$ ) (Fig. 1; Mann-Whitney U test: $P=0.25 ; \quad$ Supplementary Table 1). Excluding hypolimnetic communities, a similar result was found (Mann-Whitney U test: $P=0.11$ ) while when excluding only summer hypolimnetic communities a significant difference in ASV richness was found (MannWhitney U test: $P=0.04$; Supplementary Table 1) indicating higher mean richness in under-ice (richness $_{\mathrm{ASV}}=289 \pm 55$ ) than in summer samples (richness $_{\mathrm{ASV}}=253 \pm 56$ ). Considering all layers, betadiversity was higher during summer than under ice (betadisper analysis; $P<0.01$; Fig. 2a; Supplementary Table 1); however, excluding hypolimnetic communities (all hypolimnetic or only summer hypolimnetic communities), no statistically significant difference was found (betadisper analysis; $P=0.48$ and $P=0.46$, respectively) (Fig. 2b; Supplementary 


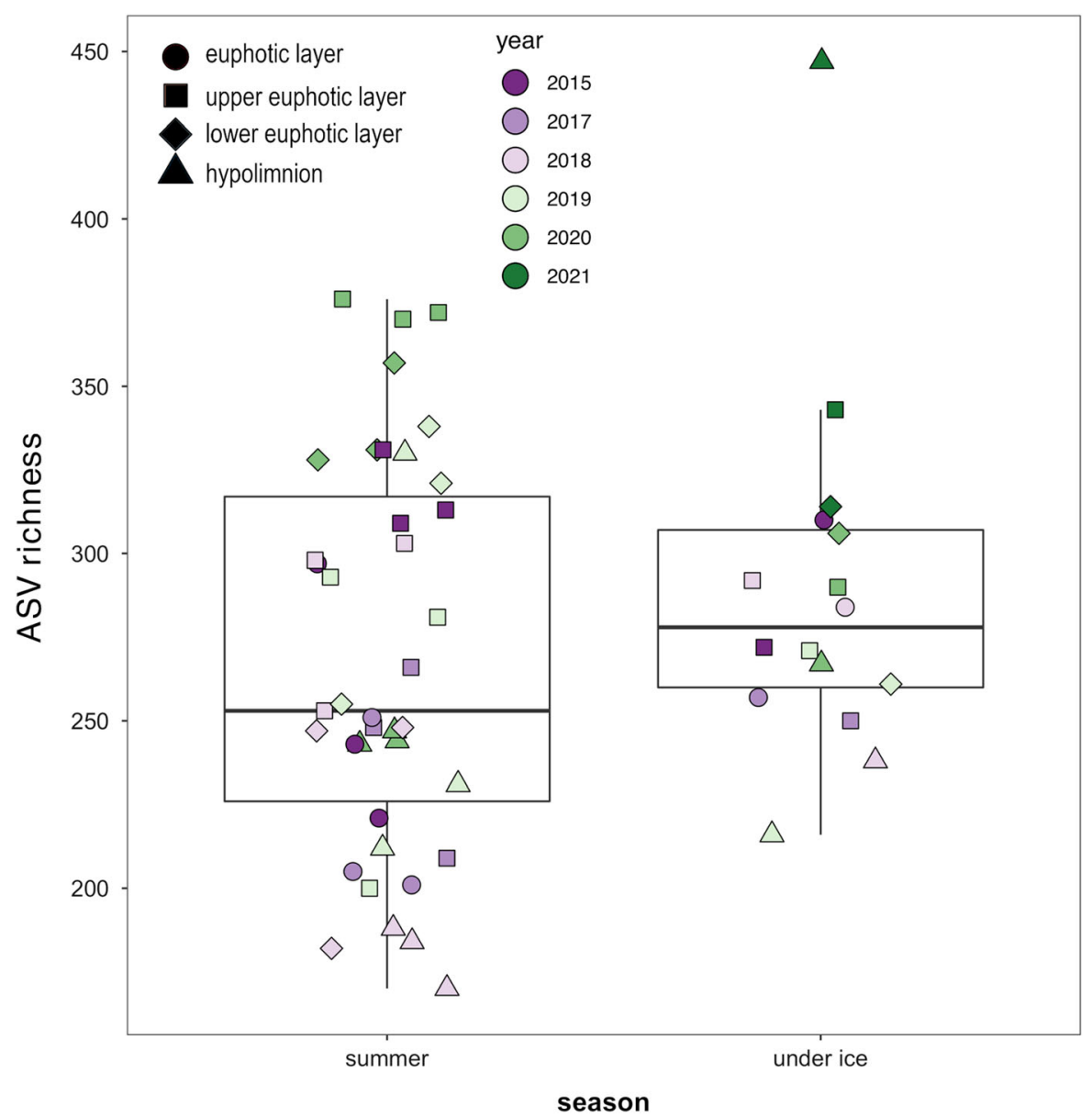

Fig. 1 Boxplot with observed values for ASV richness in summer and under-ice communities; symbols refer to layers and colours to years

Table 1). In NMDS (stress $=0.14$ ), a clear separation between summer and under-ice bacterial communities of all layers was found, except for the hypolimnion showing a clustering of summer with under-ice communities (Fig. 2a). In ANOSIM, when comparing all summer versus under-ice communities no difference was found $(R$-value $=0.11 ; P=0.03)$ while when excluding all hypolimnetic communities or summer hypolimnetic communities the R-statistic indicated a significant difference $(R$-value $=0.52$ and 0.64, respectively; $P<0.001$ ).

In ANCOM-BC with all communities, few ASVs (number of tested ASVs ranged from 1834 to 2124 dependent on the composition of the 100 random communities; $n_{\text {significant ASVs }}=3$ ) showed significant halving or doubling from summer to under ice. More ASVs were statistically significant when excluding all hypolimnetic (range of tested ASVs: 1608-1832; $n_{\text {significant } \mathrm{ASVs}}=28$ ) or only summer hypolimnetic communities (range of tested ASVs: 1872-2068; $n_{\text {significant }} \quad$ ASVs $\left.=50\right) \quad$ (Supplementary Table 2). Excluding summer hypolimnetic communities because responsible for the non-detection of seasonal differences (see betadisper, ANOSIM, NMDS), most significant ASVs of classes Actinobacteria, Acidimicrobiia, Verrucomicrobiae, Alpha- and Gammaproteobacteria increased, while ASVs of Cyanobacteria and Bdellovibrionia decreased from summer to under ice. In ANCOM-BC comparing summer and under-ice hypolimnetic communities, only 10 ASVs of over 1000 tested ASVs (range: 1111-1304) showed a statistically significant doubling $(80 \%)$ or halving (20\%) of their abundance (Table 2). 


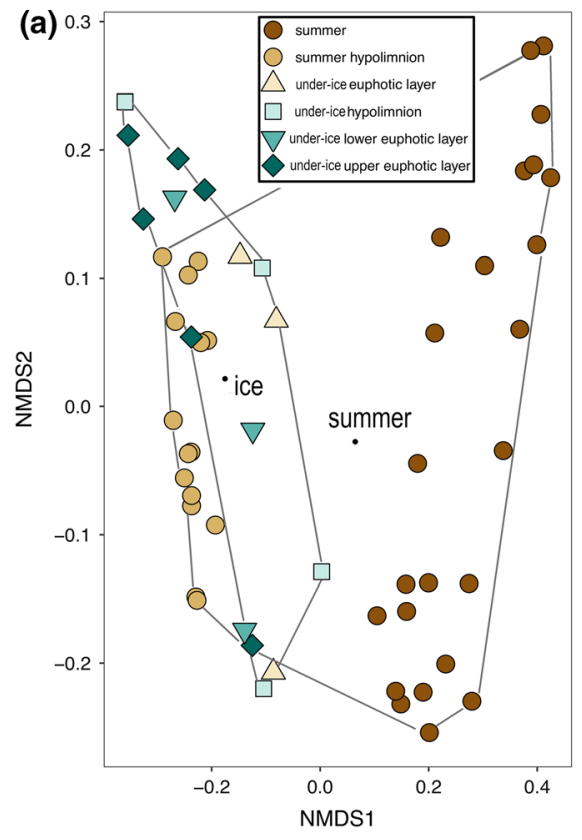

Fig. 2 NMDS with ASVs and abundance-weighted BrayCurtis dissimilarity for summer and under-ice communities; a all communities, b excluding summer hypolimnetic

\section{Under-ice environment}

For the years investigated, ice thickness ranged from 27 to $40 \mathrm{~cm}$, and ice cover was snow free in 2017 while in other years precipitation quantity was variable with highest snow cover in 2021 (Table 3). Five days before sampling, the under-ice light transparency (no data for 2015) was lowest in 2021 (no under-ice light) and highest in 2017 with respect to 2018 (Turkey HSD: $P<0.05$ ) and 2019 (Turkey HSD: $P<0.01$ ). Secchi disk depth as proxy for light attenuation was

Table 3 Environmental parameters for the under-ice period: chlorophyll- $a(\operatorname{chl}-a)$ values for the 0-20 m layer, Secchi disk depth $(\mathrm{SD} ; \mathrm{m})$, and ice depth $(\mathrm{cm})$ for the day of sampling; coefficient of attenuation for PAR $\left(\mathrm{kd}_{\mathrm{PAR}}\right.$; average and

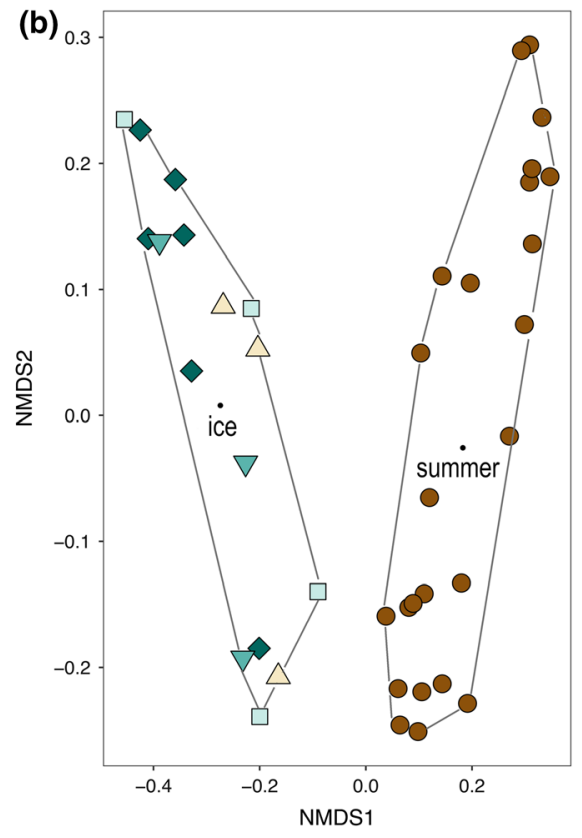

communities. The centroids of multivariate dispersion (black points; under-ice communities [ice]) and the envelope (continuous line) of summer and under-ice communities are shown

lowest in 2015 and highest in 2017. Inverse stratification with temperatures between 4 and $5{ }^{\circ} \mathrm{C}$ at depths deeper than $5 \mathrm{~m}$ (Fig. 3) was found. Most under-ice $\%$ DO profiles showed hypoxic $(\mathrm{DO}<20 \%)$ conditions at depths deeper than $30 \mathrm{~m}$ except for the 2015 profile (Fig. 3). Absorption at $254 \mathrm{~nm}$ along the water column was highest in 2015, followed by 2019, 2021, 2017, and 2018, and lowest in 2020 (Fig. 3). Chl$a(0-20 \mathrm{~m})$ was highest in 2017 and 2018 and lowest in 2021 and 2015 (Table 3). Similarly, chl- $a$ profiles were highest until a depth of $10 \mathrm{~m}$ in 2017 and 2018,

standard deviation — sd) for 5 days before sampling; the depth (m) of $1 \%$ light was calculated based on the average $\mathrm{kd}_{\mathrm{PAR}}$; precipitation (precip.; mm)

\begin{tabular}{|c|c|c|c|c|c|c|c|}
\hline \multirow[t]{2}{*}{ Year } & \multicolumn{4}{|l|}{ Day of sampling } & \multicolumn{2}{|l|}{ Sensor data } & \multirow[t]{2}{*}{ Precip. since ice-in to sampling } \\
\hline & Days since ice-in & chl- $a$ & SD & Ice depth & $\mathrm{kd}_{\mathrm{PAR}} \pm \mathrm{sd}$ & Depth $_{1 \% \text { light }}$ & \\
\hline 2015 & 33 & 1.15 & 6.8 & 38 & \multicolumn{2}{|l|}{ No sensor data } & 49.8 \\
\hline 2017 & 26 & 2.45 & 17.4 & 35 & $0.14 \pm 0.01$ & 33.9 & 0 \\
\hline 2018 & 51 & 2.23 & 10.5 & 40 & $0.17 \pm 0.03$ & 25.3 & 180 \\
\hline 2019 & 39 & 1.73 & 8.4 & 40 & $0.20 \pm 0.03$ & 22.9 & 1.6 \\
\hline 2020 & 54 & 1.52 & 8.7 & 40 & $0.16 \pm 0.01$ & 27.5 & 76 \\
\hline 2021 & 65 & 0.17 & 9.4 & 27 & \multicolumn{2}{|c|}{ No under-ice light } & 360 \\
\hline
\end{tabular}



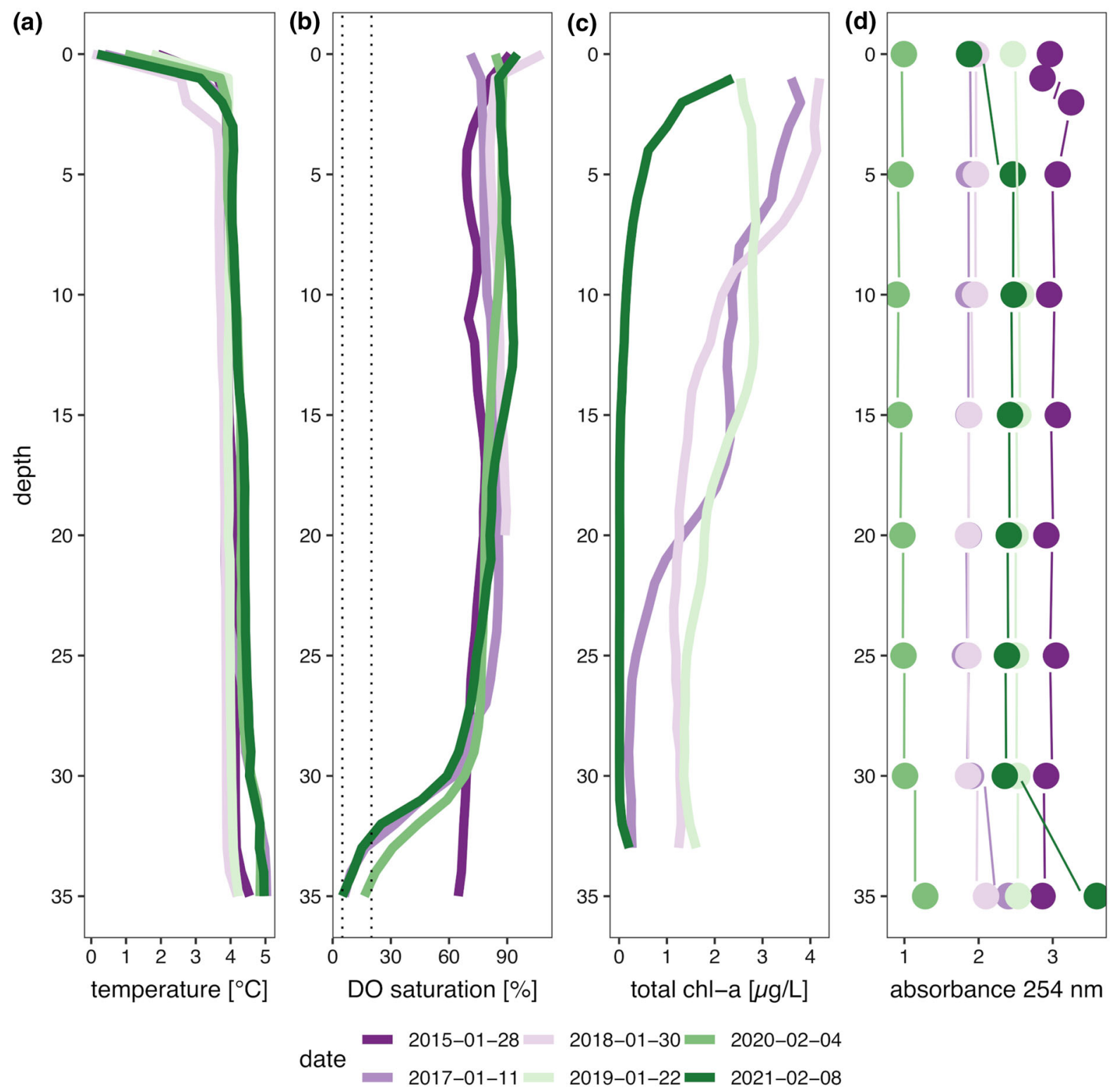

Fig. 3 Under-ice profiles of a temperature, $\mathbf{b} \% \mathrm{DO}, \mathbf{c}$ chl- $a$, and d $254 \mathrm{~nm}$ absorbance; in 2018, the multiparametric probe stopped recording at $20 \mathrm{~m}$, and thus fluoroprobe temperature values were used; in 2019, the oxygen sensor of the

were lower until $10 \mathrm{~m}$ and higher until $20 \mathrm{~m}$ in 2019, while chl- $a$ values were lowest along the entire water column in 2021 (Fig. 3). Based on these results, the environment in 2017 and 2021 presented two extremes regarding light conditions and primary production, and years were divided into two groups (group1: 2015, 2019, 2021 versus group2: 2017, 2018, 2020; Supplementary Table 3).

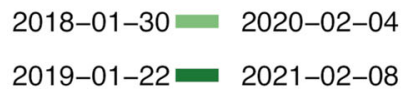

multiparametric probe did not work; in 2015 and 2020, malfunctioning of the equipment led to missing chl- $a$ profiles; the vertical dashed lines indicate anoxic $(<5 \%$ DO) and hypoxic $(<20 \%$ DO) conditions

In the PCA with under-ice environmental variables, the first two axes explained $53.6 \%$ of variability (Fig. 4); \%DO and nitrate were positively related to the upper layers while temperature and other nutrients to the hypolimnion. The confidence intervals for the centroid of the upper layers overlapped but were distinct from the centroid of the hypolimnion. Testing for environmental heterogeneity of layers (analysis 


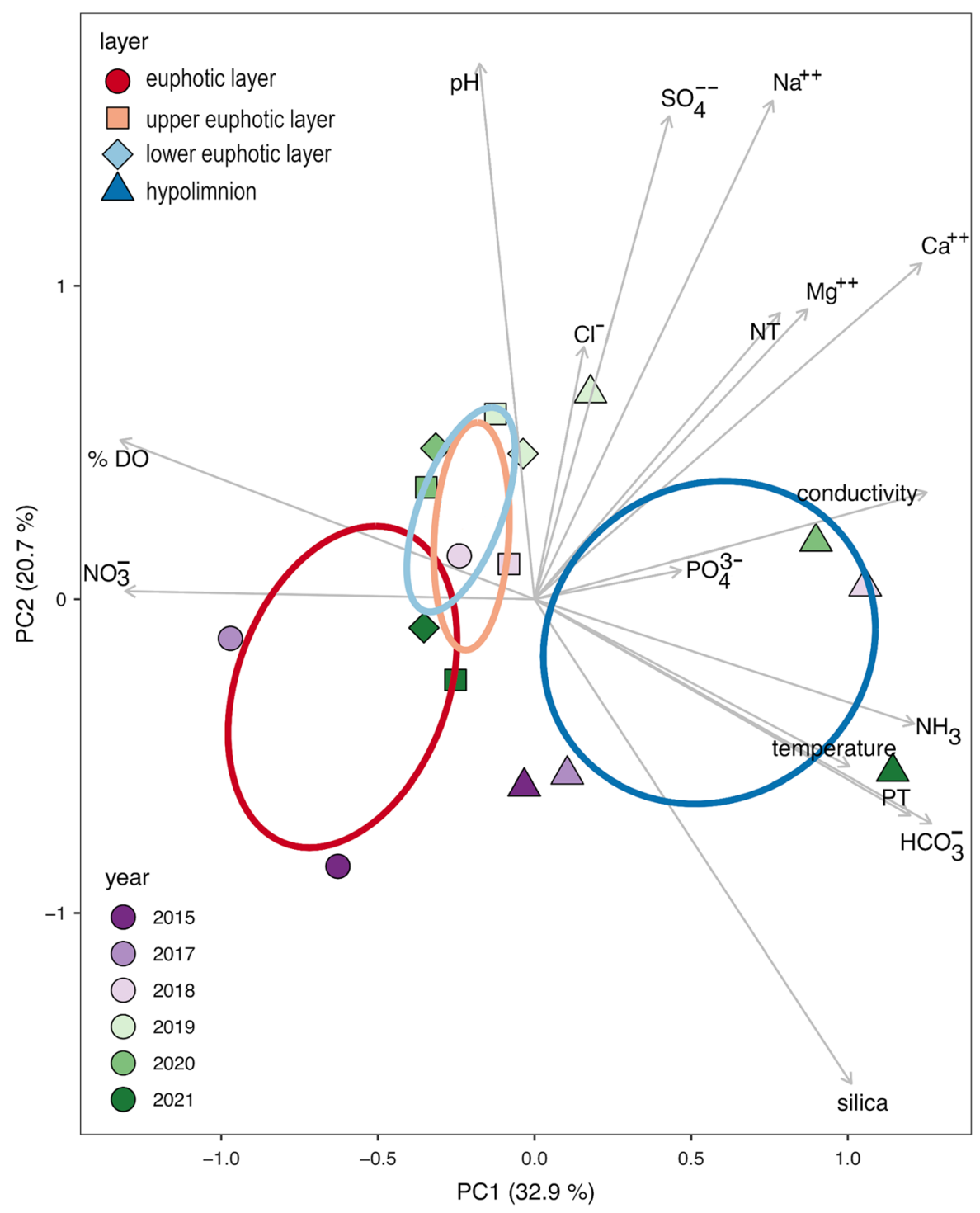

Fig. 4 PCA with standardized under-ice environmental variables; shown are the $95 \%$ confidence intervals for the layer centroid; total nitrogen (NT), total phosphorous (NP)

betadisper), the environmental diversity of the hypolimnion was higher than that of the euphotic layers when taken together (homogeneity of group dispersion, $P<0.01$; Supplementary Fig. 2).

Under-ice bacterial diversity

Observed richness of ASVs ranged between 216 (upper euphotic layer, 2019) and 447 (upper euphotic layer, 2021), and there was a tendency of higher ASV richness in 2021 with respect to other years (Fig. 1).
The percent of unique ASVs within years between layers was highest for the hypolimnion in 2019 and 2020 and for the upper euphotic layer in 2021 (Table 4; Supplementary Fig. 1). The percent of unique ASVs within layers between years was highest for the euphotic layer in 2015, for the upper euphotic layer and the hypolimnion in 2021, and for the lower euphotic layer in 2020 and 2021 (Table 5; Supplementary Fig. 1).

Focussing on the percent contribution of bacterial classes of the 50 most abundant ASVs to community 
Table 4 Percent of unique ASVs comparing layers for the years 2019 to 2021 as assessed by a Venn diagram

\begin{tabular}{llll}
\hline & Upper euphotic layer & Lower euphotic layer & Hypolimnion \\
\hline 2019 & 9 & 11 & 18 \\
2020 & 16 & 15 & 23 \\
2021 & 38 & 12 & 17 \\
\hline
\end{tabular}

Table 5 Percent of unique ASVs comparing years for each layer as assessed by a Venn diagram; no samples were taken for layers with empty cells

\begin{tabular}{llllrrr}
\hline & 2015 & 2017 & 2018 & 2019 & 2020 & 2021 \\
\hline Euphotic layer & 25 & 14 & 18 & & & \\
Upper euphotic layer & & & 10 & 8 & 15 & 41 \\
Lower euphotic layer & 5 & 5 & 7 & 4 & 21 & 21 \\
Hypolimnion & 5 & & & & 6 & 8 \\
\hline
\end{tabular}

composition (Fig. 5), some classes showed a decrease, an increase or a mixture between increase and decrease in years of group1 $(2015,2019,2021)$ and group2 (2017, 2018, 2020). Group1-related findings were (Fig. 5) as follows: Acidimicrobiia and Actinobacteria showed lowest values in all or only the lowest layers in 2021, respectively; in addition, Actinobacteria showed similarly low values also in the upper layers in 2015 and 2019. Cyanobacteria showed the lowest epilimnetic values in 2021, the highest hypolimnetic value in 2015, and the highest epilimnetic values in 2015 and 2019. Planctomycetes showed highest values in all layers in 2019 and 2021 while Alphaproteobacteria only in the hypolimnion in 2019 and 2021. Gammaproteobacteria always showed higher hypolimnetic values than in the other layers except for 2021 when the upper epilimnion showed the highest value. Bacteroidia showed lowest values in the euphotic layers in 2019 and 2021. Group-2 related findings were as follows: SL56 showed highest values in 2017 and 2018 for the euphotic layer and hypolimnion. Group1- and group2-related findings were as follows: Verrucomicrobiae showed consistently low values in all layers in 2019, showed the lowest values in the hypolimnion in 2017, and showed highest values in the lower euphotic zone and hypolimnion in 2021. Phycisphaerae showed lowest values in 2015 and 2017 and highest values in the euphotic layers in 2020 and lower euphotic layer in
2021. Anaerolineae showed highest values in the hypolimnion in 2020 and in all layers in 2021.

In NMDS (stress $=13 \%$ ) with under-ice ASVs, communities from the same year generally clustered together (Fig. 6); in addition, two clusters (communities from years 2015, 2019, and 2021 versus those from 2017, 2018, and 2020) of communities were found. In environmental fitting, only hydrogen carbonate was related to the ordination showing highest values for the 2015, 2019, and 2021 communities. In ANOSIM, differences in microbial communities between years were found $(R=0.61, P<0.001)$ while not between layers; layer differences were also not found by clustering communities of the euphotic layers together. In ANOSIM, the importance of years increased $(R=0.69, P<0.001)$ by excluding the years with less samples for communities $(2015,2017)$. Partitioning the variability of communities between environmental parameters, only year was important (PERMANOVA: $R^{2}=6 \%, P<0.001$ ) while environmental variables, including the first two $P C$ axes of the PCA based on environmental parameters, were non-significant.

In ANCOM-BC testing for differences between communities of group1 $(2015,2019,2021)$ versus group2 $(2017,2018,2020)$, only 18 bacterial classes of 61 showed changes from group1 to group2 (Table 6; Supplementary Table 4); in total, 212 out of 1491 ASVs showed statistically significant differences with 


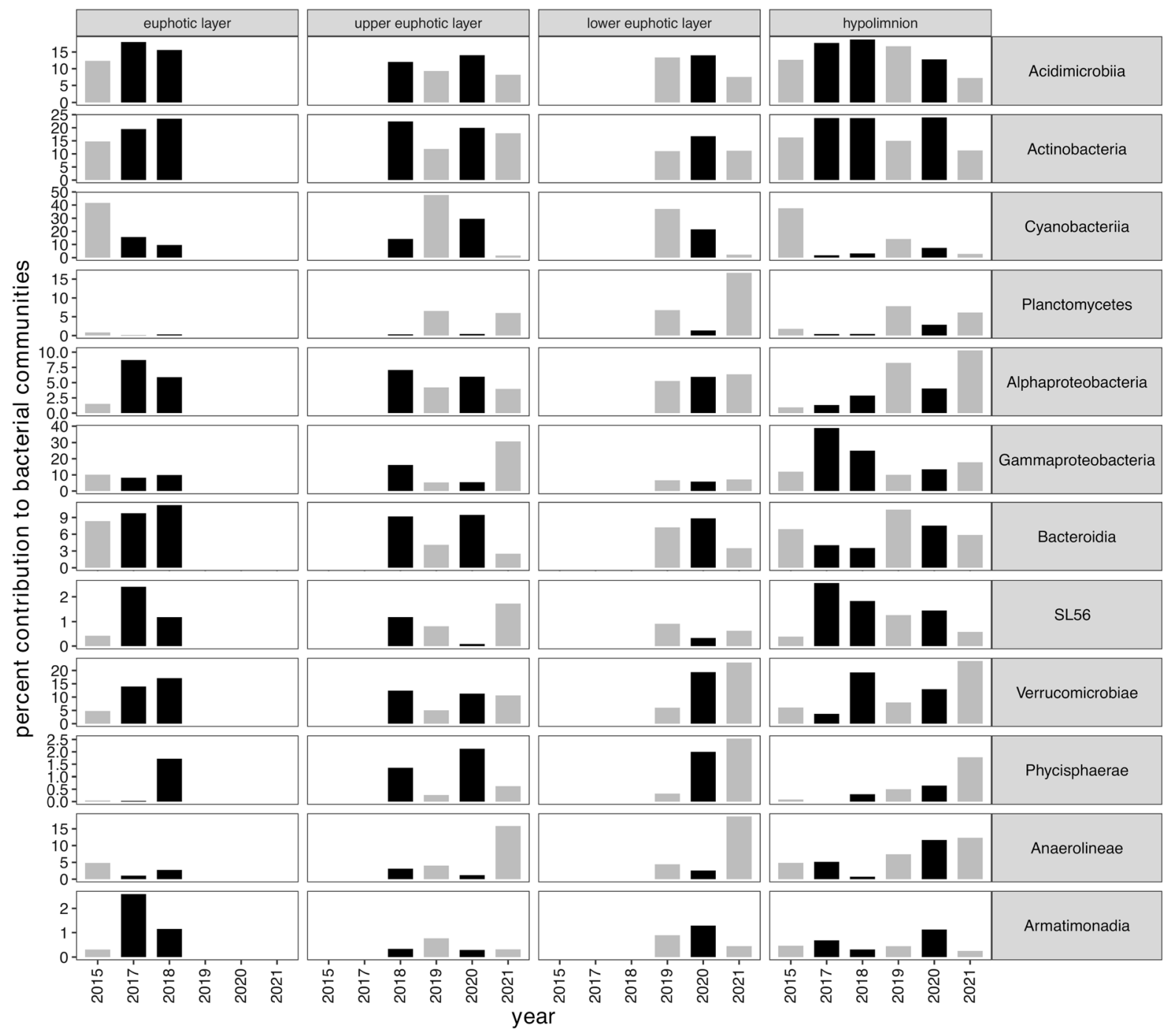

Fig. 5 Percent contribution of different bacterial classes to under-ice communities in layers and years; group1 (grey colour; years 2015, 2019, 2021), group2 (black colour; years 2017, 2018, 2020)

146 ASVs showing at least a doubling (39\%) or halving $(61 \%)$ of their abundance (Table 6; Supplementary Table 5). In detail, all significant ASVs of classes Actinobacteria and Acidimicrobiia and almost all ASVs of Verrucomicrobia and Anaerolineae showed a decrease, while ASVs of classes Alpha-, Gammaproteobacteria, Bacteroidia, Cyanobacteria, and Planctomycetes showed both an increase and decrease from group1 to group2.

\section{Discussion}

Summer versus under-ice bacterial communities

In recent years, a paradigm shift occurred from seeing winter as a stable, on-hold period to recognizing its dynamic nature and importance for the following seasons (Hampton et al., 2017). Generally, summer and under-ice bacterial communities differ in their taxonomic composition (Bertilsson et al., 2013; Vigneron et al., 2019; Cruaud et al., 2020). Here, a similar result was found (i.e. clear distinction between summer and under-ice communities) even though 


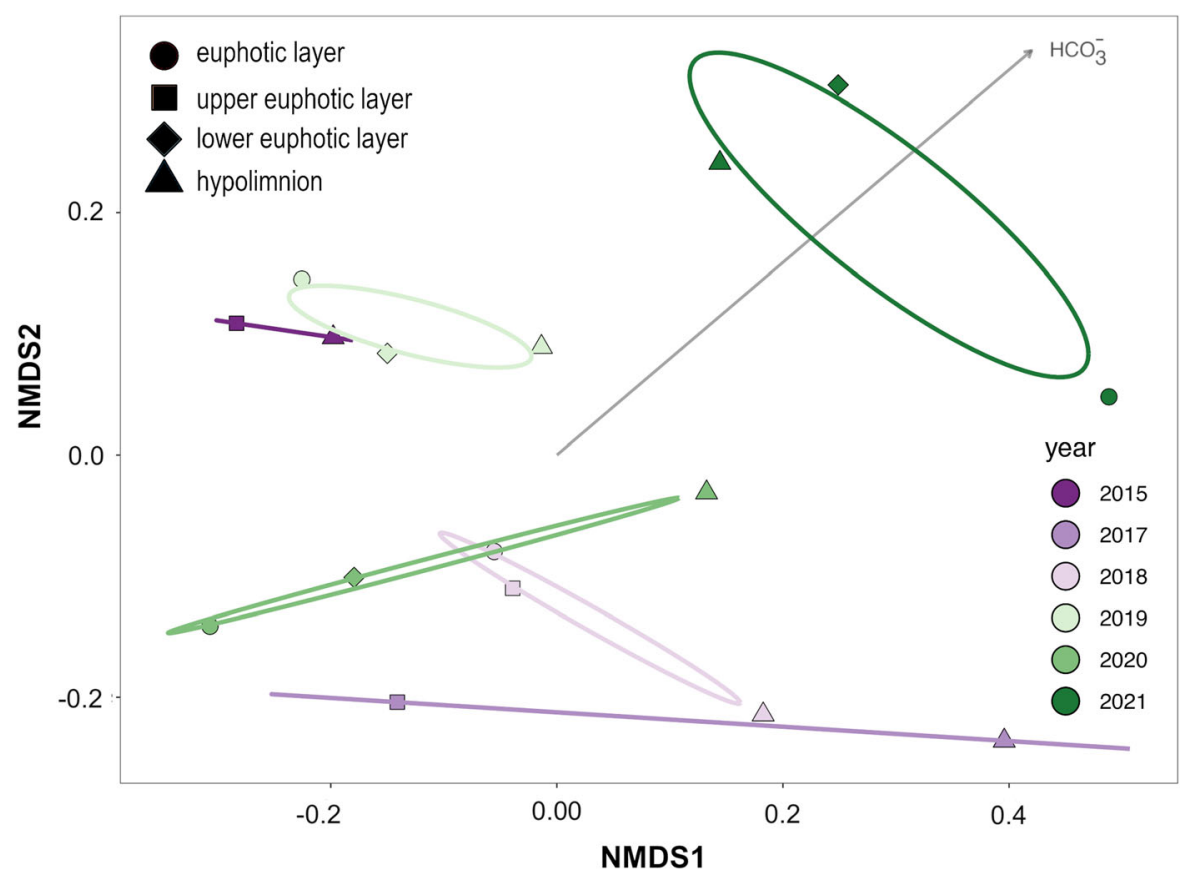

Fig. 6 NMDS with under-ice ASVs and abundance-weighted Bray-Curtis dissimilarity (stress $=13 \%$ ) and environmental fitting of variables (only hydrogen carbonate was statistically

summer hypolimnetic communities were similar to under-ice ones as hypothesized. Similar environmental conditions (cold, low \%DO) in both seasons might be responsible. Nevertheless, few hypolimnetic ASVs showed a seasonal change, and most increased in abundance from summer to under ice indicating that also in the hypolimnion specialists for under-ice conditions, characterized by scarcer resources, exist. For example, ASVs belonging to the clades Sulfuritalea and PnecC (both class Gammaproteobacteria) increased while that of the clade Flavobacterium (class Bacteroidia) decreased from summer to under ice. Sulfuritalea bacteria are adapted to nitrate-depleted hypoxic waters and perform sulphur oxidation (Watanabe et al., 2017), PnecC bacteria are adapted to oxygen depletion (Salcher et al., 2008; Linz et al., 2017) and are ecologically classified as oligotrophic ultramicrobacteria (Salcher, 2014), while Flavobacteria can be linked to bacterial production and cyanobacterial blooms (Eiler and Bertilsson, 2007; Bagatini et al., 2014).

Contrary to expectations, mean under-ice ASV richness was not different from summer, considering all layers or without hypolimnetic communities. A significant); shown are the $95 \%$ confidence intervals for the year centroids of communities

similar result was found in urban lakes showing no difference in alpha diversity of surface bacterioplankton (Fournier et al., 2021). Only the exclusion of summer hypolimnetic communities indicated a seasonal difference. As expected, beta-diversity was higher in summer than under ice but was similar when excluding hypolimnetic communities. Because hypolimnetic summer and under-ice bacterial communities were similar, the inclusion of hypolimnetic communities into statistical testing of seasonal differences dampened differences. Thus, only the exclusion of summer hypolimnetic communities allowed the uncovering of seasonal differences.

Excluding hypolimnetic summer communities, few ASVs showed a seasonal change. Lake Tovel is a coldwater lake (Cellamare et al., 2016), and the prevailing bacterial community might be already adapted to low water temperature during summer and under ice. Furthermore, no single bacterial class was characteristic for summer or under-ice conditions because several ASVs of the same class increased or decreased from summer to under ice, as already found in other studies (Butler et al., 2019; Cruaud et al., 2020). Here, the most prominent results were discussed. Among the 
Table 6 Under-ice bacterial classes with their total number of ASVs (nr ASVs) and the number of ASVs showing at least a statistically significant doubling (increase) or halving (decrease) from group1 (years 2015, 2019, 2021) to group2 (years 2017, 2018, 2020)

\begin{tabular}{lrcc}
\hline Class & nr ASVs & Increase & Decrease \\
\hline Acidimicrobiia & 35 & & 9 \\
Actinobacteria & 68 & & 5 \\
Alphaproteobacteria & 185 & 7 & 10 \\
Anaerolineae & 29 & 1 & 3 \\
Bacilli & 2 & 1 & \\
Bacteroidia & 203 & 8 & 15 \\
Bdellovibrionia & 12 & 3 & \\
Chlamydiae & 12 & 1 & \\
Cloacimonadia & 1 & 1 & \\
Cyanobacteria & 115 & 10 & 13 \\
Desulfuromonadia & 9 & 1 & \\
Gammaproteobacteria & 334 & 16 & 14 \\
Kapabacteria & 5 & & 1 \\
Parcubacteria & 74 & 1 & 1 \\
Phycisphaerae & 15 & 1 & \\
Planctomycetes & 32 & 4 & \\
Saccharimonadia & 7 & & 1 \\
Verrucomicrobiae & 125 & 2 & \\
\hline
\end{tabular}

ASVs with changing abundance, photoautotrophic Cyanobacteria and the only Bdellovibrionia ASV, tribe Peredibacter, decreased from summer to under ice. The decrease of Cyanobacteria can be linked to less under-ice light compared to summer; however, many ASVs of Cyanobacteria did not show any change implying adaptation to low-light conditions. Predatory bacteria of Bdellovibrio and like bacteria depend on specific prey and high temperature (Williams \& Chen, 2020), with the latter factor definitely missing under ice. Most ASVs of classes Actinobacteria and all of Acidimicrobiia increased from summer to under ice, consistent with other studies showing that Actinobacteria are among the most abundant phyla under ice (Møller et al., 2013; Eronen-Rasimus et al., 2014; Bashenkhaeva et al., 2015). Rhodopsin found in Actinobacteriota hints at a photoheterotrophic metabolism (Sharma et al., 2009; Martinez-Garcia et al., 2012; Ghylin et al., 2014a, b). Furthermore, Actinobacteria can obtain both carbon and nitrogen from the same substrates (Ghylin et al., 2014a, b) and are stress resistant by a high potential for DNA repair (Garcia et al., 2013). At low temperature, the concentration of reactive oxygen species increases (De Maayer et al., 2014). Thus, a photoheterotrophic metabolism, high efficiency in nutrient acquisition, and adaptation to cold stress can constitute the decisive advantage under ice when exploiting limited resources ranging from scarce light to scarce nutrients compared to summer. Summer and under-ice communities were different, and a detailed look at underice conditions and communities provided a better understanding of the underlying environmental factors.

\section{Under-ice environmental conditions}

The under-ice environment is the result of a complex interaction between physical, chemical, and biological conditions. Light-driven under-ice convection keeps phytoplankton in the photic zone (Yang et al., 2020), and ice and snow cover thickness determine the underice light transparency, DOC content, and primary production (Garcia et al., 2019; Granados et al., 2020; Huang et al., 2020; Hazuková et al., 2021). In Lake Tovel, under-ice environmental conditions were generally characterized by inverse stratification classifiable as cryostratified according to Yang et al. (2021), low dissolved oxygen and high nutrient concentrations in the hypolimnion. Comparing years, high absorbance at $256 \mathrm{~nm}$ as proxy for DOC was found in 2015 , 2019, and 2021. These years were characterized by intense precipitation events before ice-in in 2014, 2018, and 2020, respectively (Supplementary Fig. 3), that most probably brought allochthonous material with surface runoff from the surrounding forest into the lake. Allochthonous material is chemically recalcitrant to microbial degradation but high abundance compensates for low degradation (Wetzel, 2001; Salcher, 2014). Lake Tovel is oligotrophic and DOC is scarce ( $<1 \mathrm{mg} \mathrm{L}^{-1}$; Obertegger et al., 2007), and additional nutrient supply might be readily used under ice, both by bacteria and phytoplankton that compete and depend on each other in their nutrient supply (Salcher, 2014; Mühlenbruch et al., 2018; Elovaara et al., 2021). In 2015, the highly oxygenated hypolimnion was most likely related to carry-over effects from an extreme event in the previous year that increased hypolimnetic DO saturation (Flaim et al., 2020) than by nutrient input-linked primary 
production, as indicated by a relatively low chl- $a$. In 2019, the high chl- $a$ in correspondence with high transparency indicated sufficient nutrient supply. In 2021, chl- $a$ was lowest, linked to low transparency and any phytoplankton-bacteria coupling (e.g. Elovaara et al., 2021) might have been impaired. In 2020, the relatively low under-ice chl- $a$, despite relatively high transparency, could be related to nutrient shortage because it did not rain for 18 days before ice-in in 2019. In contrast, no precipitation from ice-in in 2016 to sampling in 2017 was related to highest transparency favourable for algal growth as indicated by highest chl- $a$. In 2021, the thinnest ice and highest snow cover and light attenuation corresponded to lowest chl- $a$ values. In summary, under-ice conditions were different between years linked to nutrient input before ice-in, under-ice light transparency, and primary production, and this led to the year grouping. The years of group1 and group2 generally reflected light (i.e. high-light versus low-light) and chl- $a$ differences (high versus low primary production). In the discussion, the terminology high-light versus low-light years was used for simplicity because primary production is inherently connected to under-ice light (Cavaliere et al., 2021). Generally, heterotrophic bacteria do not directly depend on light (but see Sharma et al. (2009); Martinez-Garcia et al. (2012); Ghylin et al. (2014a, b) for photoheterotrophic bacteria) but indirectly through decomposition of under-ice algal blooms or uptake of algal-derived compounds (Bertilsson et al., 2013; Salcher, 2014) while cyanobacteria depend on light availability, and thus the year grouping was related to both, direct and indirect effects of light availability.

In addition to these general environmental differences between years, the hypolimnion showed a higher environmental variability than the euphotic layer as indicated by the PCA and betadisper analysis based on standardized under-ice environmental variables. In an inter-habitat comparison (littoral, pelagic, hypolimnion), the hypolimnion is considered the most environmentally stable (Obertegger et al., 2018), and hypolimnetic bacterial communities are considered more stable because the hypolimnion is more sheltered from climatic events (Linz et al., 2017). These studies, however, compared large-scale differences across seasons and habitats that most probably obscured the fine-scale environmental differences observed under ice.
Under-ice bacterial communities

Life in a cold environment poses many challenges for sustaining metabolic activity and growth. Under ice, many bacteria down-regulate their metabolism (Tribelli \& López, 2018), and microbes with low energy requirements are favoured (Tran et al., 2018); however, as shown for psychrophilic phytoplankton in Lake Tovel (Obertegger et al., 2011; Flaim et al., 2012, 2014), also some bacteria like it cold (De Maayer et al., 2014).

Overall, alpha diversity (richness of ASVs, the percentage of unique ASVs) of the year 2021 was different with respect to other years. This might indicate that low-light conditions have a greater influence on communities than high-light conditions. Here, considerations about the distribution of bacterial classes in layers and years together with the increase or decrease of single ASVs from high-light to low-light years (ANCOM-BC) helped to gain a better understanding of environmental influences. The most striking results were discussed. Only $10 \%$ of ASVs increased or decreased from high-light to low-light years implying that most bacteria did not respond to direct and/or indirect effects of the changing under-ice light climate or the year grouping did not completely reflect their environmental preferences. In the uppermost layer, Cyanobacteria showed their lowest \% contribution to bacterial communities in 2021 , linkable to low-light conditions. In oligotrophic lakes, Cyanobacteria quickly increase in abundance with the addition of phosphorus (Molot et al. 2021), and Cyanobacteria can dominate in hypolimnetic waters at low-light conditions (Hamre et al., 2018). The unusual Cyanobacteria increase in the hypolimnion in 2015 might be related to a higher nutrient load because of pre-ice precipitation in 2014.

Alphaproteobacteria showed highest abundance in high-light years in the euphotic layer as well as in lowlight years in the hypolimnion, while single ASVs increased as well decreased from high-light to lowlight years. For example, most ASVs of clade alfV-A, tribe LD12, decreased while one increased from highlight to low-light years. These bacteria are aerobic heterotrophs occurring during summer in the epilimnion (Salcher et al., 2011), are adapted to oligotrophic conditions (Henson et al., 2018), require certain amino acids and vitamins from external sources (Henson et al., 2018), and are controlled by 
phage infection (Chen et al., 2019). Thus, their decline was related to unfavourable under-ice conditions while a temperature-dependent ecotype diversification within LD12 (Henson et al., 2018) might apply to the single exception.

Gammaproteobacteria generally showed highest values in the hypolimnion with many ASVs increasing or decreasing from high-light to low-light years. Gammaproteobacteria are opportunistic bacteria growing rapidly (Eronen-Rasimus et al., 2014), and this might explain their prevalence in the nutrient-rich hypolimnion. ASVs of Methylobacter, Candidatus Nitrotoga, and Methylotenera decreased from highlight to low-light years; these ASVs are potential methylotrophic Gammaproteobacteria and play a major role in aerobic environments during winter (Samad \& Bertilsson, 2017). Their decrease might be related to fewer photosynthetic Cyanobacteria producing aerobically methane (Bižić et al., 2020) and/or an oxygen deficit (Smith et al., 2018).

Classes Actinobacteria and Acidimicrobiia decreased mostly in all layers in 2021, and all ASVs of these classes decreased from high-light to low-light years. Direct and indirect effects of light limitation might have been responsible because their photoheterotrophic metabolism (Sharma et al., 2009; Martinez-Garcia et al., 2012; Ghylin et al., 2014a, b) and uptake of algal exudates (Maresca et al., 2019) might have been impaired at low-light conditions. ASVs of Actinobacteria and Acidimicrobiia that increased from summer to under ice were different from those decreasing from high to low light indicating that a different community was involved in seasonal changes and changes under ice. Similarly to the above two classes, class Bacteroidia decreased in euphotic layers in low-light years 2019 and 2021, and many ASVs decreased from high-light to low-light years. Bacteroidetes are attached to particles and degrade polymeric compounds (FernándezGómez et al., 2013), and are often linked to cyanobacterial blooms (Woodhouse et al., 2016; Scherer et al., 2017); thus, phytoplankton decrease under low-light conditions might have been responsible for Bacteroidia decrease in the under-ice euphotic zone.

In all layers, Anaerolineae showed increased prevalence in bacterial communities in 2021 and Planctomycetes in 2019 and 2021, both low-light years. Most ASVs of Planctomycetes confirmed this general class pattern and increased from high-light to low-light years while most ASVs of Anaerolineae decreased, indicating that single ASVs determined the pattern of the class. Anaerolineae and Planctomycetes have the genetic potential for micro-oxygen and thiosulfate respiration and the degradation of aromatic carbon and plant detritus (Vigneron et al., 2019). Planctomycetes are poor competitors for phosphorus, are slow growing (Pollet et al., 2014), and are very specialized such as to low temperature (Andrei et al., 2019). In 2021, degradation of complex organic material probably constituted an advantage when algal exudates were possibly scarce because of no under-ice light. In 2019, reduced nutrient competition with phytoplankton and precipitation-driven input of nutrients probably drove the increase of Planctomycetes.

Verrucomicrobiae showed a decrease in low-light year 2019 and an increase in low-light year 2021 in the lowest layers while most ASVs decreased from highlight to low-light years. Verrucomicrobiae are well adapted to a chemo-lithotrophic life under ice (Tran et al., 2018), and this might be responsible for the weaker link to under-ice light and primary production than other classes showed. Similarly, Phycisphaerae increased both in high-light year 2020 in the euphotic layers and low-light year 2021 in the hypolimnion and the lowest euphotic layer, and the single significant ASV increased from high-light to low-light years. Bacteria of Phycisphaerae are linked to the degradation of plant-derived organic matter (Ivanova et al., 2018), and the degradation of decaying algae under no-light conditions might be linked to their increase in 2021.

The only class showing a clear response to highlight conditions in 2017 (i.e. increase in the epilimnion and hypolimnion) was SL56 of phylum Chloroflexi even though no ASV showed significant changes from high-light to low-light years. The SL56 cluster is seen as epilimnion-specific, and in some groups of SL56 the primarily heterotrophic life style is boosted by lightdriven energy generation via rhodopsin (Mehrshad et al., 2018); this light dependency could explain the increase of the class SL56 in 2017.

In summary, the pattern of bacterial classes and ASVs with respect to the year grouping indicated direct and indirect dependencies on light availability and primary production even though the year grouping not always reflected environmental preferences. Bacteria compete with algae for nutrients and profit from 
the release of algal exudate that can be used by bacteria (Salcher, 2014), while light is important for photosynthetic organisms, under-ice convection of nutrients (Yang et al., 2020), and photodegradation of dissolved organic matter (Hampton et al., 2017). Within classes, ASVs of the same lineage, clade, or tribe showed different dependencies on the year grouping, and this indicated the high adaptation potential of bacteria. Also NMDS based on under-ice ASVs corroborated the importance of under-ice light and primary production as only hydrogen carbonate was linked to the ordination. In phytoplankton, the transport of hydrogen carbonate and conversion to $\mathrm{CO}_{2}$ is an important carbon concentrating mechanism (Raven, 1991). The higher concentration of hydrogen carbonate in the years with low-light conditions might be linked to reduced photosynthesis. In low-light conditions and especially in 2021 certain bacteria might have been released from competition with algae for nutrients as indicated by the higher diversity in 2021 with respect to other years, especially for the upper euphotic layer where competition might have been strongest. Despite significant indications of the importance of light availability and primary production for under-ice communities, other, not lightmediated influencing factors such as viral lysis, grazing by flagellates (Salcher, 2014), and interspecies interactions (e.g. Gerphagnon et al., 2015) that were not covered by this study might also have determined ASV patterns from one year to another.

In multivariate analyses (ANOSIM, PERMANOVA), no influence of layers on under-ice bacterial diversity was found. Under-ice hypolimnetic conditions (i.e. low temperature, low-light intensity, low nutrient availability) extend over most of the water column, and therefore a strict distinction in upper and lower euphotic zone can be unnecessary, especially in years with no under-ice light. For example, Planctomycetes showed highest values in all layers in lowlight years 2019 and 2021, and also Gammaproteobacteria showed similarly high values in the upper epilimnion and the hypolimnion in low-light year 2021. Planctomycetes are seen as hypolimnion-specific under non-inverse stratification conditions (Okazaki et al., 2017) and Gammaproteobacteria show highest hypolimnetic values during summer (Obertegger et al., 2018). However, this spatial distinction was not perceivable with limited light availability under ice.

\section{Summary}

The under-ice habitat can be considered dynamic because light conditions can rapidly change depending on precipitation and temperature that change ice and snow transparency. While the presented results are snap shots of the under-ice microbial communities, continuous temporal studies of under-ice communities similar to Butler et al. (2019) are hampered by safety and logistic issues. This study showed that different under-ice bacterial communities developed each year linked to light transparency and primary production. The amount of snow will drastically decrease with climate change, especially at mid-elevations (Scherrer et al., 2004; Schöner et al., 2009; Marcolini et al., 2017). Thus, future under-ice conditions might be more characteristic of high-light years with important implications for microbial community composition.

Acknowledgements This work was supported by FEM internal research funding. The author thanks Lorena Ress, Gianpietro Svaldi, Milva Tarter, and Andrea Zampedri for technical assistance.

Open Access This article is licensed under a Creative Commons Attribution 4.0 International License, which permits use, sharing, adaptation, distribution and reproduction in any medium or format, as long as you give appropriate credit to the original author(s) and the source, provide a link to the Creative Commons licence, and indicate if changes were made. The images or other third party material in this article are included in the article's Creative Commons licence, unless indicated otherwise in a credit line to the material. If material is not included in the article's Creative Commons licence and your intended use is not permitted by statutory regulation or exceeds the permitted use, you will need to obtain permission directly from the copyright holder. To view a copy of this licence, visit http://creativecommons.org/licenses/by/4.0/.

Data availability The datasets generated during and/or analysed during the current study are available from the corresponding author on reasonable request. Under-ice sequence data have been deposited at the National Center for Biotechnological Information (NCBI) - sequence read archive (SRA) under accession number PRJNA727741, summer data are available in the EMBL database under Accession number PRJEB25090 and PRJEB32348. 


\section{References}

Andrei, A. Ş, M. M. Salcher, M. Mehrshad, P. Rychtecký, P. Znachor \& R. Ghai, 2019. Niche-directed evolution modulates genome architecture in freshwater Planctomycetes. The ISME Journal 13: 1056-1071.

Anderson, M. J., K. E. Ellingsen \& B. H. McArdle, 2006. Multivariate dispersion as a measure of beta diversity. Ecology Letters 9: 683-693.

APHA, 2017. Standard Methods for the Examination of Water and Wastewater, 23rd ed. American Public Health Association/American Water Works Association/Water Environment Federation, Washington DC:

Apprill, A., S. McNally, R. Parsons \& L. Weber, 2015. Minor revision to V4 region SSU rRNA 806R gene primer greatly increases detection of SAR11 bacterioplankton. Aquatic Microbial Ecology 75: 129-137.

Bagatini, I. L., A. Eiler, S. Bertilsson, D. Klaveness, L. P. Tessarolli \& A. A. H. Vieira, 2014. Host-specificity and dynamics in bacterial communities associated with bloomforming freshwater phytoplankton. PloS ONE 9: e85950.

Bashenkhaeva, M. V., Y. R. Zakharova, D. P. Petrova, I. V. Khanaev, Y. P. Galachyants \& Y. V. Likhoshway, 2015. Sub-ice microalgal and bacterial communities in freshwater Lake Baikal, Russia. Microbial Ecology 70: 751-765.

Beall, B. F. N., M. R. Twiss, D. E. Smith, B. O. Oyserman, M. J. Rozmarynowycz, C. E. Binding, R. A. Bourbonniere, G. S. Bullerjahn, M. E. Palmer \& E. D. Reavie, 2016. Ice cover extent drives phytoplankton and bacterial community structure in a large north-temperate lake: implications for a warming climate. Environmental Microbiology 18: 1704-1719.

Benson, B. J., J. J. Magnuson, O. P. Jensen, V. M. Card, G. Hodgkins, J. Korhonen, D. M. Livingstone, K. M. Stewart, G. A. Weyhenmeyer \& N. G. Granin, 2012. Extreme events, trends, and variability in Northern Hemisphere lake-ice phenology (1855-2005). Climatic Change 112: 299-323.

Bertilsson, S., A. Burgin, C. C. Carey, S. B. Fey, H.-P. Grossart, L. M. Grubisic, I. D. Jones, G. Kirillin, J. T. Lennon \& A. Shade, 2013. The under-ice microbiome of seasonally frozen lakes. Limnology and Oceanography 58: 1998-2012.

Bižić, M., T. Klintzsch, D. Ionescu, M. Y. Hindiyeh, M. Günthel, A. M. Muro-Pastor, W. Eckert, T. Urich, F. Keppler \& H.-P. Grossart, 2020. Aquatic and terrestrial cyanobacteria produce methane. Science Advances 6: eaax5343.

Bižić-Ionescu, M., R. Amann \& H.-P. Grossart, 2014. Massive regime shifts and high activity of heterotrophic bacteria in an ice-covered lake. PLoS ONE 9: e113611.

Block, B. D., B. A. Denfeld, J. D. Stockwell, G. Flaim, H.-P.F. Grossart, L. B. Knoll, D. B. Maier, R. L. North, M. Rautio \& J. A. Rusak, 2019. The unique methodological challenges of winter limnology. Limnology and Oceanography: Methods 17: 42-57.

Bolsenga, S. J. \& H. A. Vanderploeg, 1992. Estimating photosynthetically available radiation into open and ice-covered freshwater lakes from surface characteristics; a high transmittance case study. Hydrobiologia 243: 95-104.
Butler, T. M., A.-C. Wilhelm, A. C. Dwyer, P. N. Webb, A. L. Baldwin \& S. M. Techtmann, 2019. Microbial community dynamics during lake ice freezing. Scientific Reports 9: 1-11.

Callahan, B. J., P. J. McMurdie \& S. P. Holmes, 2017. Exact sequence variants should replace operational taxonomic units in marker-gene data analysis. The ISME Journal 11: 2639-2643.

Callahan, B. J., P. J. McMurdie, M. J. Rosen, A. W. Han, A. J. A. Johnson \& S. P. Holmes, 2016. DADA2: high-resolution sample inference from Illumina amplicon data. Nature Methods 13: 581-583.

Cavaliere, E., I. B. Fournier, V. Hazuková, G. P. Rue, S. Sadro, S. A. Berger, J. B. Cotner, H. A. Dugan, S. E. Hampton, N. R. Lottig \& B. C. McMeans, 2021. The lake ice continuum concept: influence of winter conditions on energy and ecosystem dynamics. Journal of Geophysical Research: Biogeosciences 126: e2020JG006165.

Cellamare, M., A. M. Lancon, M. Leitão, L. Cerasino, U. Obertegger \& G. Flaim, 2016. Phytoplankton functional response to spatial and temporal differences in a cold and oligotrophic lake. Hydrobiologia 764: 199-209.

Charvet, S., W. F. Vincent \& C. Lovejoy, 2014. Effects of light and prey availability on Arctic freshwater protist communities examined by high-throughput DNA and RNA sequencing. FEMS Microbiology Ecology 88: 550-564.

Chen, L.-X., Z. Yanlin, K. D. McMahon, J. F. Mori, G. L. Jessen, T. Colenbrander Nelson, L. A. Warren, \& J. F. Banfield, 2019. Distribution of Phage That Infect Freshwater SAR11 Bacteria. mSystems 4: e00410-19

Cruaud, P., A. Vigneron, M.-S. Fradette, C. C. Dorea, A. I. Culley, M. J. Rodriguez \& S. J. Charette, 2020. Annual bacterial community cycle in a seasonally ice-covered river reflects environmental and climatic conditions. Limnology and Oceanography 65: 21-37.

De Maayer, P., D. Anderson, C. Cary \& D. A. Cowan, 2014. Some like it cold: understanding the survival strategies of psychrophiles. EMBO Reports 15: 508-517.

Dusa, A., 2021. venn: Draw Venn Diagrams. R package version 1.10. https://CRAN.R-project.org/package $=$ venn

Eiler, A. \& S. Bertilsson, 2007. Flavobacteria blooms in four eutrophic lakes: linking population dynamics of freshwater bacterioplankton to resource availability. Applied and Environmental Microbiology 73: 3511-3518.

Elovaara, S., E. Eronen-Rasimus, E. Asmala, T. Tamelander \& H. Kaartokallio, 2021. Contrasting patterns of carbon cycling and dissolved organic matter processing in two phytoplankton-bacteria communities. Biogeosciences 18 : 6589-6616.

Eronen-Rasimus, E., H. Kaartokallio, C. Lyra, R. Autio, H. Kuosa, G. S. Dieckmann \& D. N. Thomas, 2014. Bacterial community dynamics and activity in relation to dissolved organic matter availability during sea-ice formation in a mesocosm experiment. Microbiology Open 3: 139-156.

Fernández-Gómez, B., M. Richter, M. Schüler, J. Pinhassi, S. G. Acinas, J. M. González, C. Pedrós-Alió, 2013. Ecology of marine Bacteroidetes: a comparative genomics approach. ISME Journal 7: 1026-1037.

Flaim, G., D. Andreis, S. Piccolroaz \& U. Obertegger, 2020. Ice cover and extreme events determine dissolved oxygen in a 
placid mountain lake. Water Resources Research 56: e2020WR027321.

Flaim, G., U. Obertegger, A. Anesi \& G. Guella, 2014. Temperature-induced changes in lipid biomarkers and mycosporine-like amino acids in the psychrophilic dinoflagellate Peridinium aciculiferum. Freshwater Biology 59: 985-997.

Flaim, G., U. Obertegger \& G. Guella, 2012. Changes in galactolipid composition of the cold freshwater dinoflagellate Borghiella dodgei in response to temperature. Hydrobiologia 698: 285-293.

Fournier, I. B., C. Lovejoy \& W. F. Vincent, 2021. Changes in the community structure of under-ice and open-water microbiomes in urban lakes exposed to road salts. Frontiers in Microbiology 12: 660719.

Garcia, S. L., A. J. Szekely, C. Bergvall, M. Schattenhofer \& S. Peura, 2019. Decreased snow cover stimulates under-ice primary producers but impairs methanotrophic capacity. mSphere 4: e00626-18.

Garcia, S. L., K. D. McMahon, M. Martinez-Garcia, A. Srivastava, A. Sczyrba, R. Stepanauskas, H. P. Grossart, T. Woyke \& F. Warnecke, 2013. Metabolic potential of a single cell belonging to one of the most abundant lineages in freshwater bacterioplankton. The ISME Journal 7: 137-147.

Gerphagnon, M., D. J. Macarthur, D. Latour, C. M. Gachon, F. Van Ogtrop, F. H. Gleason \& T. Sime-Ngando, 2015. Microbial players involved in the decline of filamentous and colonial cyanobacterial blooms with a focus on fungal parasitism. Environmental Microbiology 17: 2573-2587.

Ghylin, T. W., S. L. Garcia, F. Moya, B. O. Oyserman, P. Schwientek, K. T. Forest, J. Mutschler, J. Dwulit-Smith, L.-K. Chan \& M. Martinez-Garcia, 2014a. Comparative single-cell genomics reveals potential ecological niches for the freshwater acI Actinobacteria lineage. The ISME Journal 8: 2503-2516.

Granados, I., M. Toro, S. Giralt, A. Camacho \& C. Montes, 2020. Water column changes under ice during different winters in a mid-latitude Mediterranean high mountain lake. Aquatic Sciences 82: 1-19.

Grubisic, L. M., S. Bertilsson, A. Eiler, F. Heinrich, A. Brutemark, L. Alonso-Sáez, A. F. Andersson, S. Gantner, L. Riemann \& S. Beier, 2017. Lake bacterioplankton dynamics over diurnal timescales. Freshwater Biology 62: 191-204.

Ghylin, T. W., S. L. Garcia, F. Moya, B. O. Oyserman, P. Schwientek, K. T. Forest, J. Mutschler, J. Dwulit-Smith, L. K. Chan, M. Martinez-Garcia \& A. Sczyrba, 2014b. Comparative single-cell genomics reveals potential ecological niches for the freshwater acI Actinobacteria lineage. The ISME Journal 8: 2503-2516.

Hampton, S. E., A. W. Galloway, S. M. Powers, T. Ozersky, K. H. Woo, R. D. Batt, S. G. Labou, C. M. O'Reilly, S. Sharma $\&$ N. R. Lottig, 2017. Ecology under lake ice. Ecology Letters 20: 98-111.

Hamre, K. D., M. E. Lofton, R. P. McClure, Z. W. Munger, J. P. Doubek, A. B. Gerling, M. E. Schreiber \& C. C. Carey, 2018. In situ fluorometry reveals a persistent, perennial hypolimnetic cyanobacterial bloom in a seasonally anoxic reservoir. Freshwater Science 37: 483-495.
Hazuková, V., B. T. Burpee, I. McFarlane-Wilson \& J. E. Saros, 2021. Under ice and early summer phytoplankton dynamics in two Arctic lakes with differing DOC. Journal of Geophysical Research: Biogeosciences 126: e2020JG005972.

Henson, M. W., V. C. Lanclos, V.C., B. C. Faircloth \& J. C. Thrash, 2018. Cultivation and genomics of the first freshwater SAR11 (LD12) isolate. ISME Journal 12: 1846-1860.

Herlemann, D. P. R., M. Labrenz, K. Juergens, S. Bertilsson, J. J. Waniek \& A. F. Anderrson, 2011. Transition in bacterial communities along the $2000 \mathrm{~km}$ salinity gradient of the Baltic Sea. The ISME Journal 5: 1571-1579.

Hrycik, A. R. \& J. D. Stockwell, 2021. Under-ice mesocosms reveal the primacy of light but the importance of zooplankton in winter phytoplankton dynamics. Limnology and Oceanography 66: 481-495.

Huang, X., C. G. Weisener, J. Ni, B. He, D. Xie \& Z. Li, 2020. Nitrate assimilation, dissimilatory nitrate reduction to ammonium, and denitrification coexist in Pseudomonas putida Y-9 under aerobic conditions. Bioresource Technology 312: 123597.

Huber, W., V. Carey, R. Gentleman, S. Anders, M. C. Benilton, S. Carvalho, H. Corrada Bravo, S. Davis, L. Gatto, T. Girke, R. Gottardo, F. Hahne, K. D. Hansen, R. A. Irizarry, M. Lawrence, M. I. Love, J. MacDonald, V. Obenchain, A. K. Oleś, H. Pagès, A. Reyes, P. Shannon, G. K. Smyth, D. Tenenbaum, L. Waldron \& M. Morgan, 2015. Orchestrating high-throughput genomic analysis with Bioconductor. Nature Methods 12: 115-121.

Ivanova, A. A., D. A. Philippov, I. S. Kulichevskaya \& S. N. Dedysh, 2018. Distinct diversity patterns of Planctomycetes associated with the freshwater macrophyte Nuphar lutea (L.) Smith. Antonie Van Leeuwenhoek Springer 111: 811-823.

Jewson, D. H., N. G. Granin, A. A. Zhdanov \& R. Y. Gnatovsky, 2009. Effect of snow depth on under-ice irradiance and growth of Aulacoseira baicalensis in Lake Baikal. Aquatic Ecology 43: 673-679.

Kalinowska, K. \& M. Grabowska, 2016. Autotrophic and heterotrophic plankton under ice in a eutrophic temperate lake. Hydrobiologia 777: 111-118.

Kirillin, G., M. Leppäranta, A. Terzhevik, N. Granin, J. Bernhardt, C. Engelhardt, T. Efremova, S. Golosov, N. Palshin \& P. Sherstyankin, 2012. Physics of seasonally ice-covered lakes: a review. Aquatic Sciences 74: 659-682.

Lin, H. \& S. D. Peddada, 2020. Analysis of compositions of microbiomes with bias correction. Nature Communications 11: 1-11.

Linz, A. M., B. C. Crary, A. Shade, S. Owens, J. A. Gilbert, R. Knight \& K. D. McMahon, 2017. Bacterial community composition and dynamics spanning five years in freshwater bog lakes. mSphere 2: e00169-e217.

Llorens-Marès, T., S. Yooseph, J. Goll, J. Hoffman, M. VilaCosta, C. M. Borrego, C. L. Dupont \& E. O. Casamayor, 2015. Connecting biodiversity and potential functional role in modern euxinic environments by microbial metagenomics. The ISME Journal 9: 1648-1661.

Magnuson, J. J., D. M. Robertson, B. J. Benson, R. H. Wynne, D. M. Livingstone, T. Arai, R. A. Assel, R. G. Barry, V. Card $\&$ E. Kuusisto, 2000. Historical trends in lake and river ice 
cover in the Northern Hemisphere. Science 289: 1743-1746.

Marcolini, G., A. Bellin, M. Disse \& G. Chiogna, 2017. Variability in snow depth time series in the Adige catchment. Journal of Hydrology 13: 240-254.

Maresca, J. A., J. L. Keffer, P. P. Hempel, S. W. Polson, O. Shevchenko, J. Bhavsar, D. Powell, K. J. Miller, A. Singh \& M. W. Hahn, 2019. Light modulates the physiology of nonphototrophic Actinobacteria. Journal of Bacteriology 201: e00740-e818.

Martinez-Garcia, M., B. K. Swan, N. J. Poulton, M. L. Gomez, D. Masland, M. E. Sieracki \& R. Stepanauskas, 2012. High-throughput single-cell sequencing identifies photoheterotrophs and chemoautotrophs in freshwater bacterioplankton. The ISME Journal 6: 113-123.

Matyugina, E. \& N. Belkova, 2015. Distribution and diversity of microbial communities in meromictic soda Lake Doroninskoe (Transbaikalia, Russia) during winter. Chinese Journal of Oceanology and Limnology 33: 1378-1390.

Mehrshad, M., M. M. Salcher, Y. Okazaki, S. Nakano, K. Šimek, A.-S. Andrei \& R. Ghai, 2018. Hidden in plain sight-highly abundant and diverse planktonic freshwater Chloroflexi. Microbiome 6: 1-13.

Mikhailov, I. S., Y. P. Galachyants, Y. S. Bukin, D. P. Petrova, M. V. Bashenkhaeva, M. V. Sakirko, V. V. Blinov, L. A. Titova, Y. R. Zakharova \& Y. V. Likhoshway, 2021. Seasonal Succession and Coherence Among Bacteria and Microeukaryotes in Lake Baikal. Microbial Ecology. https://doi.org/10.1007/s00248-021-01860-2.

Molot, L. A., S. N. Higgins, S. L. Schiff, J. J. Venkiteswaran, M. J. Paterson \& H. M. Baulch, 2021. Phosphorus-only fertilization rapidly initiates large nitrogen-fixing cyanobacteria blooms in two oligotrophic lakes. Environmental Research Letters. https://doi.org/10.1088/1748-9326/ ac0564.

Møller, A. K., D. A. Søborg, W. Abu Al-Soud, S. J. Sørensen \& N. Kroer, 2013. Bacterial community structure in HighArctic snow and freshwater as revealed by pyrosequencing of 16S rRNA genes and cultivation. Polar Research 32: 17390.

Monier, A., H. S. Findlay, S. Charvet \& C. Lovejoy, 2014. Late winter under ice pelagic microbial communities in the high Arctic Ocean and the impact of short-term exposure to elevated $\mathrm{CO}_{2}$ levels. Frontiers in Microbiology 5: 490.

Mühlenbruch, M. \& H. P., Grossart, F., Eigemann, \& M. Voss, 2018. Mini-review: Phytoplankton-derived polysaccharides in the marine environment and their interactions with heterotrophic bacteria. Environmental Microbiology 20: 2671-2685.

Obertegger, U., S. Bertilsson, M. Pindo, S. Larger \& G. Flaim, 2018. Temporal variability of bacterioplankton is habitat driven. Molecular Ecology 27: 4322-4335.

Obertegger, U., F. Camin, G. Guella \& G. Flaim, 2011. Adaptation of a psychrophilic freshwater dinoflagellate to ultraviolet radiation. Journal of Phycology 47: 811-820.

Obertegger, U., G. Flaim, M. G. Braioni, R. Sommaruga, F. Corradini \& A. Borsato, 2007. Water residence time as a driving force of zooplankton structure and succession. Aquatic Sciences 69: 575-583.
Obertegger, U., G. Flaim \& R. Sommaruga, 2008. Multifactorial nature of rotifer water layer preferences in an oligotrophic lake. Journal of Plankton Research 30: 633-643.

Obertegger, U., B. Obrador \& G. Flaim, 2017. Dissolved oxygen dynamics under ice: Three winters of high-frequency data from Lake Tovel, Italy. Water Resources Research 53: 7234-7246.

Okazaki, Y., S. Fujinaga, A. Tanaka, A. Kohzu, H. Oyagi \& S. Nakano, 2017. Ubiquity and quantitative significance of bacterioplankton lineages inhabiting the oxygenated hypolimnion of deep freshwater lakes. The ISME Journal 11: 2279-2293.

Oksanen, J., F. G. Blanchet, M. Friendly, R. Kindt, P. Legendre, D. McGlinn, P. R. Minchin, R. B. O'Hara, G. L. Simpson, P. Solymos, M. H. H. Stevens, E. Szoecs \& H. Wagner, 2020. vegan: Community Ecology Package. R package version 2.5-7. https://CRAN.R-project.org/package=vegan

O’Reilly, C. M., S. Sharma, D. K. Gray, S. E. Hampton, J. S. Read, R. J. Rowley, P. Schneider, J. D. Lenters, P. B. McIntyre \& B. M. Kraemer, 2015. Rapid and highly variable warming of lake surface waters around the globe. Geophysical Research Letters 42: 10773-10781.

Pernthaler, J., F.-O. Glöckner, S. Unterholzner, A. Alfreider, R. Psenner \& R. Amann, 1998. Seasonal community and population dynamics of pelagic bacteria and archaea in a high mountain lake. Applied and Environmental Microbiology 64: 4299-4306.

Pollet, T., J. F. Humbert \& R. D. Tadonléké, 2014. Planctomycetes in lakes: poor or strong competitors for phosphorus? Applied and Environmental Microbiology 80: 819-828.

Powers, S. M., S. G. Labou, H. M. Baulch, R. J. Hunt, N. R. Lottig, S. E. Hampton \& E. H. Stanley, 2017. Ice duration drives winter nitrate accumulation in north temperate lakes. Limnology and Oceanography Letters 2: 177-186.

Price, P. B. \& T. Sowers, 2004. Temperature dependence of metabolic rates for microbial growth, maintenance, and survival. Proceedings of the National Academy of Sciences 101: 4631-4636.

Quast, C., E. Pruesse, P. Yilmaz, J. Gerken, T. Schweer, P. Yarza, J. Peplies \& F. O. Glöckner, 2012. The SILVA ribosomal RNA gene database project: improved data processing and web-based tools. Nucleic Acids Research 41: D590-D596.

Quensen, J., 2020. ggordiplots: Make ggplot Versions of Vegan's Ordiplots. R package version 0.4.0. http://github. com/jfq3/ggordiplots.

R Core Team 2020. R: A language and environment for statistical computing. R Foundation for Statistical Computing, Vienna, Austria. https://www.R-project.org/.

Raven, J. A., 1991. Implications of inorganic carbon utilization: ecology, evolution, and geochemistry. Canadian Journal of Botany NRC Research Press Ottawa, Canada 69: 908-924.

Rice, E. W., R. B. Baird, A. D. Eaton \& L. S. Clesceri, 2017. Standard methods for the examination of water and wastewater (23nd ed.). Washington, DC: American Public Health Association, American Water Works Association, Water Environment Federation.

Rohwer, R. R., J. J. Hamilton, R. J. Newton \& K. D. McMahon, 2018. TaxAss: leveraging a custom freshwater database 
achieves fine-scale taxonomic resolution. mSphere 3: e00327-18.

Rue, G. P., J. P. Darling, E. Graham, M. M. Tfaily \& D. M. McKnight, 2020. Dynamic changes in dissolved organic matter composition in a Mountain Lake under ice cover and relationships to changes in nutrient cycling and phytoplankton community composition. Aquatic Sciences 82: $1-16$.

Russel, J. 2021. MicEco: Various functions for microbial community data. $\mathrm{R}$ package version 0.9.15.

Salcher, M. M., 2014. Same same but different: ecological niche partitioning of planktonic freshwater prokaryotes. Journal of Limnology 73: 74-87.

Salcher, M. M., J. Pernthaler \& T. Posch, 2011. Seasonal bloom dynamics and ecophysiology of the freshwater sister clade of SAR11 bacteria 'that rule the waves'(LD12). The ISME Journal 5: 1242-1252.

Salcher, M. M., J. Pernthaler, M. Zeder, R. Psenner \& T. Posch, 2008. Spatio-temporal niche separation of planktonic Betaproteobacteria in an oligo-mesotrophic lake. Environmental Microbiology 10: 2074-2086.

Samad, M. S. \& S. Bertilsson, 2017. Seasonal variation in abundance and diversity of bacterial methanotrophs in five temperate lakes. Frontiers in Microbiology 8: 142.

Scherer, P. I., A. D. Millard, A. Miller, R. Schoen, U. Raeder, J. Geist \& K. Zwirglmaier, 2017. Temporal dynamics of the microbial community composition with a focus on toxic cyanobacteria and toxin presence during harmful algal blooms in two South German lakes. Frontiers in Microbiology 8: 2387.

Scherrer, S. C., C. Appenzeller \& M. Laternser, 2004. Trends in Swiss Alpine snow days: The role of local-and large-scale climate variability. Geophysical Research Letters 31: L13215.

Schöner, W., I. Auer \& R. Böhm, 2009. Long term trend of snow depth at Sonnblick (Austrian Alps) and its relation to climate change. Hydrological Processes: an International Journal 23: 1052-1063.

Sharma, A. K., K. Sommerfeld, G. S. Bullerjahn, A. R. Matteson, S. W. Wilhelm, J. Jezbera, U. Brandt, W. F. Doolittle $\&$ M. W. Hahn, 2009. Actinorhodopsin genes discovered in diverse freshwater habitats and among cultivated freshwater Actinobacteria. The ISME Journal 3: 726-737.

Smith, G. J., J. C. Angle, L. M. Solden, M. A. Borton, T. H. Morin, R. A. Daly, M. D. Johnston, K. C. Stefanik, R. Wolfe \& B. Gil, 2018. Members of the genus Methylobacter are inferred to account for the majority of aerobic methane oxidation in oxic soils from a freshwater wetland. mBio 9: e00815-18.

Sokal, R. \& J. Rohlf, 1995. Biometry: The principles and practices of statistical in biological research, W. H. Freeman and Company, New York:

Summers, R. S., P. K. Cornel \& P. V. Roberts, 1987. Molecular size distribution and spectroscopic characterization of humic substances. Science of the Total Environment 62: 27-37.

Tran, P., A. Ramachandran, O. Khawasik, B. E. Beisner, M. Rautio, Y. Huot \& D. A. Walsh, 2018. Microbial life under ice: Metagenome diversity and in situ activity of Verrucomicrobia in seasonally ice-covered Lakes. Environmental Microbiology 20: 2568-2584.
Tribelli, P. M. \& N. I. López, 2018. Reporting key features in cold-adapted bacteria. Life 8: 8.

Tulonen, T., P. Kankaala, A. Ojala \& L. Arvola, 1994. Factors controlling production of phytoplankton and bacteria under ice in a humic, boreal lake. Journal of Plankton Research 16: 1411-1432.

Twiss, M. R., R. M. L. McKay, R. A. Bourbonniere, G. S. Bullerjahn, H. J. Carrick, R. E. H. Smith, J. G. Winter, N. A. D'souza, P. C. Furey \& A. R. Lashaway, 2012. Diatoms abound in ice-covered Lake Erie: An investigation of offshore winter limnology in Lake Erie over the period 2007 to 2010. Journal of Great Lakes 38: 18-30.

Verpoorter, C., T. Kutser, D. A. Seekell \& L. J. Tranvik, 2014. A global inventory of lakes based on high-resolution satellite imagery. Geophysical Research Letters 41: 6396-6402.

Vigneron, A., C. Lovejoy, P. Cruaud, D. Kalenitchenko, A. Culley \& W. F. Vincent, 2019. Contrasting winter versus summer microbial communities and metabolic functions in a permafrost thaw lake. Frontiers in Microbiology 10: 1656.

Watanabe, T., A. Miura, T. Iwata, H. Kojima \& M. Fukui, 2017. Dominance of Sulfuritalea species in nitrate-depleted water of a stratified freshwater lake and arsenate respiration ability within the genus. Environmental Microbiology Reports 9: 522-527.

Weiss, S., Z. Z. Xu, S. Peddada, A. Amir, K. Bittinger, A. Gonzalez, C. Lozupone, J. R. Zaneveld, Y. Vázquez-Baeza \& A. Birmingham, 2017. Normalization and microbial differential abundance strategies depend upon data characteristics. Microbiome 5: 1-18.

Wetzel, R.G. 2001. Limnology Lake and Reservoir Ecosystems. Academic Press, San Diego.

Wickham, H., 2016. ggplot2: Elegant Graphics for Data Analysis, Springer-Verlag, New York:

Williams, H. N. \& H. Chen, 2020. Environmental regulation of the distribution and ecology of Bdellovibrio and like organisms. Frontiers in Microbiology 11: 2670.

Woodhouse, J. N., A. S. Kinsela, R. N. Collins, L. C. Bowling, G. L. Honeyman, J. K. Holliday \& B. A. Neilan, 2016. Microbial communities reflect temporal changes in cyanobacterial composition in a shallow ephemeral freshwater lake. The ISME Journal 10: 1337-1351.

Yang, B., M. G. Wells, J. Li \& J. Young, 2020. Mixing, stratification, and plankton under lake-ice during winter in a large lake: Implications for spring dissolved oxygen levels. Limnology and Oceanography 65: 2713-2729.

Yang, B., M. G. Wells, B. C. McMeans, H. A. Dugan, J. A. Rusak, G. A. Weyhenmeyer, J. A. Brentrup, A. R. Hrycik, A. Laas \& R. M. Pilla, 2021. A new thermal categorization of ice-covered lakes. Geophysical Research Letters 48: e2020GL091374.

Yang, B., J. Young, L. Brown \& M. Wells, 2017. High-frequency observations of temperature and dissolved oxygen reveal under-ice convection in a large lake. Geophysical Research Letters 44: 12,218-12,226.

Publisher's Note Springer Nature remains neutral with regard to jurisdictional claims in published maps and institutional affiliations. 